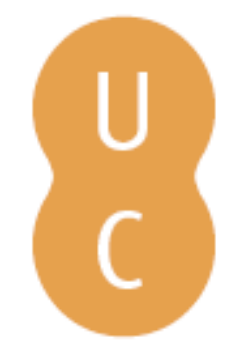

\title{
pommalina
}

\section{Review of informed consent in gynecological and obstetrical interventions with curettage: a study of 20 spanish centers}

\author{
Autor(es): $\quad$ Pinto, P.; Morillas, P.; Badía, C. \\ Publicado por: Imprensa da Universidade de Coimbra; International Academy of Legal \\ Medicine \\ URL \\ persistente: URI:http://hdl.handle.net/10316.2/31795 \\ DOI: $\quad$ DOI:http://dx.doi.org/10.14195/978-989-26-0173-1_34 \\ Accessed : $\quad$ 26-Apr-2023 08:03:23
}

A navegação consulta e descarregamento dos títulos inseridos nas Bibliotecas Digitais UC Digitalis, UC Pombalina e UC Impactum, pressupõem a aceitação plena e sem reservas dos Termos e Condições de Uso destas Bibliotecas Digitais, disponíveis em https://digitalis.uc.pt/pt-pt/termos.

Conforme exposto nos referidos Termos e Condições de Uso, o descarregamento de títulos de acesso restrito requer uma licença válida de autorização devendo o utilizador aceder ao(s) documento(s) a partir de um endereço de IP da instituição detentora da supramencionada licença.

Ao utilizador é apenas permitido o descarregamento para uso pessoal, pelo que o emprego do(s) título(s) descarregado(s) para outro fim, designadamente comercial, carece de autorização do respetivo autor ou editor da obra.

Na medida em que todas as obras da UC Digitalis se encontram protegidas pelo Código do Direito de Autor e Direitos Conexos e demais legislação aplicável, toda a cópia, parcial ou total, deste documento, nos casos em que é legalmente admitida, deverá conter ou fazer-se acompanhar por este aviso.

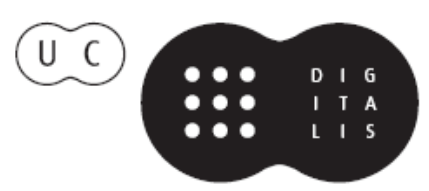




\section{Duarte Nuno Vieira Anthony Busuttil \\ Denis Cusack • Philip Beth}
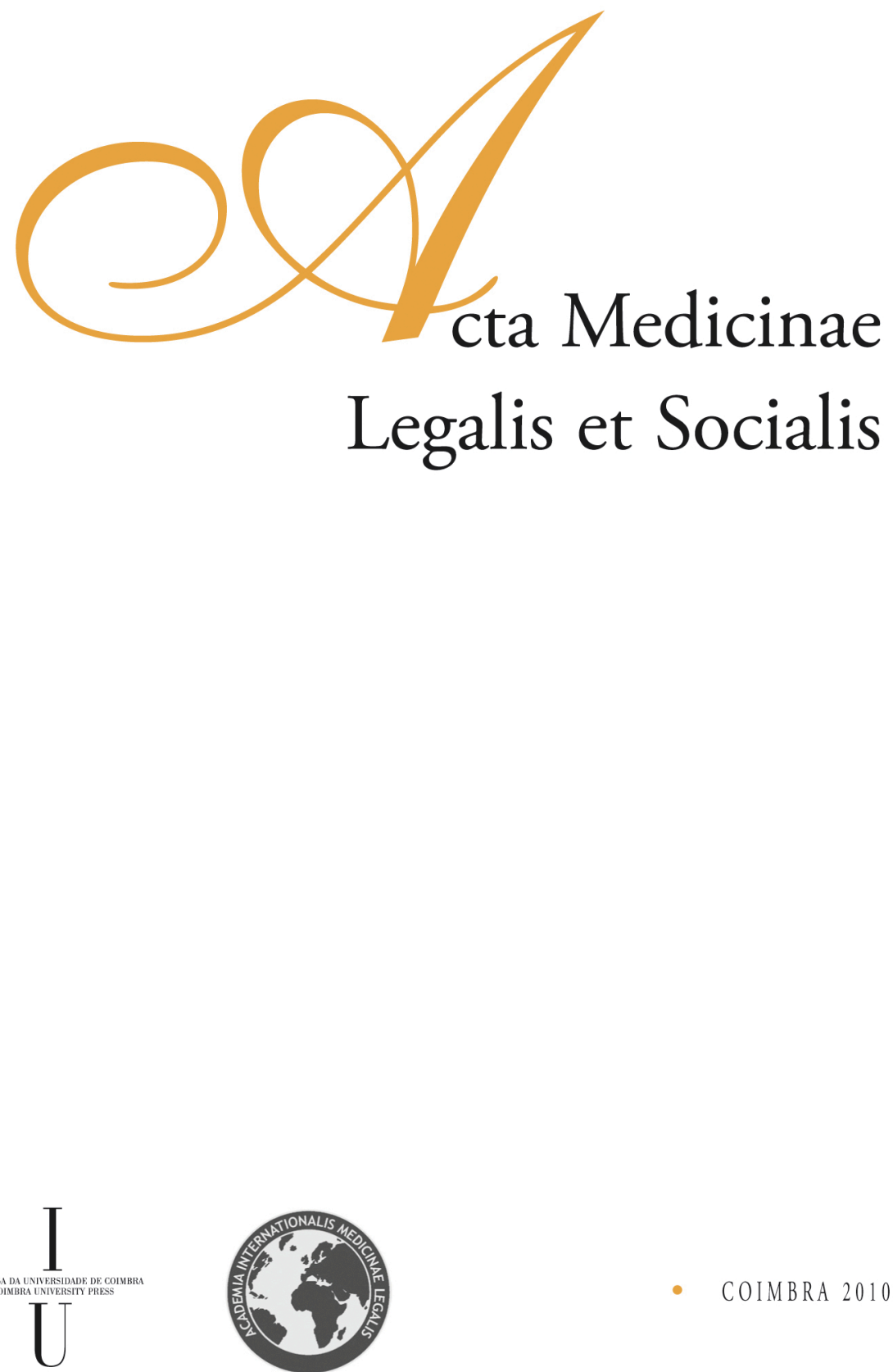
P. Pinto, V. Uroz, P. Morillas, C. Badía

Legal School of Medicine of Madrid, Faculty of Medicine, Universidad Complutense de Madrid, Spain Department of Toxicology and Legal Medicine,Madrid, Spain

\title{
REVIEW OF INFORMED CONSENT IN GYNECOLOGICAL AND OBSTETRICAL INTERVENTIONS WITH CURETTAGE: A STUDY OF 20 SPANISH CENTERS
}

\begin{abstract}
Informed consent is a very important document in legal medicine, as well as in the doctor-patient relationship. The informed consent has been widely developed in Spain with Law 41/2002 that regulates Patient Autonomy and Health Documentation and Information related Right and Obligations. The Spanish Society of Obstetrics and Gynecology suggests that many claims in their speciality have their origin in this issue. So, we reviewed this document in 20 Spanish medical centers (public and private) in curettage interventions and various medical societies and public institutions. Protocols for administration and the content of the informed consents checked were acceptable in most of them, except the private centres for voluntary interruption of pregnancy. We conclude that curettage should have a more homogeneous protocol of informed consent between public and private centres; the information should be adapted for each patient; a signed copy of the document should be given to the patient; and informed consent should be provided at least 24 hours before the intervention.
\end{abstract}

\section{Introduction}

Informed consent is a very important document in legal medicine, as well as in the doctor-patient relationship. The informed consent has been widely developed in Spain with Law 41/2002 that regulates Patient Autonomy and Health Documentation and Information related Right and Obligations.

In gynecology and obstetrics, the defects around informed consent are present in more than half of the claims according to the Spanish Society of Gynecology and Obstetrics (SEGO) in their study of Accidents (from 1994 to 2004) ${ }^{1}$.

So, it was proposed to review this document in Spanish hospitals (public and private) in curettage interventions because it is one of the most common surgical procedures in this speciality.

\footnotetext{
${ }^{1}$ Spanish Society of Gynecology and Obstetrics (SEGO). Professional Civil Responsability. Spain (1994-2004). Study developed by Uniteco Profesional.
} 
The curettage can be divided into:

- Vacuum curettage: it could be scheduled or urgent. It is the intervention when there is a delayed abortion or to remove a tumor.

- Diagnostic curettage: it is used in cases where it is necessary to obtain a sample of the endometrium or myometrium.

- Curettage for a voluntary interruption of pregnancy (VIP) or induced abortion: these are performed mostly in specialized private centres. It is also called dilatation and sharp curettage $(\mathrm{D} \& \mathrm{C})$. This curettage is often accompanied by vacuum aspiration of embryonic material and placenta tissues. In Spain, this is the procedure that it is used in more that $85 \%$ of the VIPs performed, usually in the first trimester of pregnancy.

\section{Methodology}

We have reviewed the documents of informed consent from 20 medical centres, public and private, throughout Spain. In the study they are included the different types of curettage, the moment when the informed consent is given and, finally, we have studied if the documents follows what is required by Law 41/2002 and SEGO's recommendations.

The informed consents that we looked through belonged to the following medical centres: Hospital Universitario Gregorio Marañón, Madrid Hospitals Group (three centres), Getafe's Hospital, Móstoles' Hospital, Alcorcón’s Hospital, Moncloa Hospital - ASISA, Vistahermosa Clinic - ASISA, San Jose Clinic, Ginetec Clinic, Ginemedex Clinic, EMECE Clinics (two centers), Isadora Clinic, Hospital Universitario Central de Asturias, Cabueñes' Hospital (Asturias), San Agustin's Hospital (Asturias), Talavera de la Reina's Hospital (Toledo) and Hospital Clínico de Granada. Furthermore, we studied the models recommended by the Council of Health of Valencia. Totally there were 30 models from 20 centres.

The items selected to be verified in the informed consents were:

\section{Criteria set out in Law 41/2002:}

1.1. Article 2 says that "the consent for any medical procedure must be obtained after the patient receives adequate information." Also, the law establish that the information must be "understandable" and "adequate", and it indicates in which cases the informed consent shall be in writing.

So, we introduced an item that would analyse if the explanation of the procedure was appropriate in manner and form.

1.2. Article $\mathbf{1 0}$ of Law $41 / 2002$ concerning the conditions of informed consent in writing:

"The doctor should provide information to the patients before obtaining their written consent. The information given must include at least:

a) The relevant consequences that for sure the procedure will have.

b) The risks associated with personal or professional circumstances of the patient. 
c) The risks of the technique in normal conditions and based on experience and the state of the science or directly related to the type of intervention.

d) Contraindications of the patient to this procedure."

We evaluated if all this criteria were included in the selected consents.

1.3. Article 8 of the Law: "The patients may freely revoke their consent in writing at any time."

In this case, we analysed if it was possible to revoke the consent or not.

\section{Minimum criteria for the SEGO:}

From SEGO's model we took out three items for comparison among the other documents:

It is possible or not to identify the doctor/s who give the information and who make the procedure?

Does the document mention the possibility from which transfusion of blood might be needed?

Does the informed consent include that material obtained from curettage will be sent for histopathologic exam?

\section{Results}

The results are summarized in Table 1.

The information provided and the moment when the informed consent was administrated was acceptable in most of the documents studied. On the other hand, we identified some shortcomings in content and form, especially in the explanation of the contraindications, alternatives, possible need for transfusion and information on the histopathological studies. There were three public centres (Hospital Universitario Gregorio Marañón, Móstoles' and Alcorcón's hospitals) which included a reference to the authorization for the treatment of personal data according to Spanish Law (Organic Law 15/1999).

\section{Criteria established in Law 41/2002:}

Related to items from Law 41/2002 and taking as standard the document provided by the SEGO, five centres give further information or more complete. However, most of the documents include in the explanation of the procedure incomprehensible concepts like "ovular remains", or like Isadora Clinic that includes in their list of probable risks the word "etc.", which is not suitable in these cases because they are too general.

None of the models include any reference to sure consequences of the procedure. It should be included in the VIP centers, as the sure consequence of the intervention is the induced abortion. Also, we observed that the four private centres that do the interruptions for pregnancy have lots of shortcomings in the document.

None of the informed consent models include the compulsory section of the contraindications. 


\section{Items recommended by SEGO:}

The model of informed consent proposed by the SEGO does not include two important items identified in Law 41/2002: the contraindications of the curettage and the alternatives to the procedure, including the posibility of not to perform the intervention. These posibility should be present in the case that the curettage be elective.

Moreover, the model proposed by the SEGO is basically followed by all the centres, except the inclusion of the possible need for transfusion, that it is not included in two public hospitals.

Nevertheless, informed consents of the VIP centres do not meet the criteria of the model SEGO in almost any case and they are much more incomplete than this one.

\section{Other comparative studies:}

3a. Comparison between public and private centres: if we do not include the five VIP centers, we can conclude that all the centres, four private and nine public, provide in their documents an information quite similar in quality and quantity. Anyway, the content of the informed consent from ASISA hospitals was the most complete from all, with the exception of the item of the contraindications, that it is neither included.

3b. Related to the type of curettage: there were no differences between the form and content of documents used in the informed consent of the curettage used to evacuate and the one used in the diagnosis.

3c. We have found great differences in form and content among the four VIP centres and the rest, being the former the most defective.

3d. Moment of application of informed consent: most of consulted centres reported that they provide the document at least 24 hours before the procedure, so that it could be read and studied by the patient. In some centers, the document is explained and given weeks before the intervention. However this information, we were not able to confirm it personally at any centre, nor in public, neither in private centres.

\section{Discussion:}

We have studied 30 different models of informed consent at ginecological curettage, 20 from medical centers, public and private, as well as the model propose by the Council of Health of Valencia. We have verified in each model the criteria established by Basic Regulatory Law 41/2002 on Patient Autonomy and Patient Rights and Duties Regarding Clinical Information and Documentation.

It is relevant that curettage, a procedure that, initially, we may think that is seemingly simple has shown enough differences among the documents of informed consent among the centers studied.

On the other side, it has been seen that centres that develop VIP have the documents with more shortcomings, specially in the explanation of the procedure and risks. And, in general, these clinics are not respecting Law 41/2002 and SEGO's criteria. However, we can not generalize by saying that all informed consent from clinics of VIP have poor documentation because our sample includes only four documents used 
in five centres and, in Spain, there are more than 140 public and private institutions accredited for VIP.

Information must be provided verbally and in writing to the patient. It is also important for a good comprehension that the information is adapted to the cultural level of the patient.

From what is referred in each centre, we have also deduced that, with certain exceptions not verified, information is provided in good time. By the way, the Spanish Society of Aesthetic Plastic Surgery and Repair (SECPRE) ${ }^{2}$ have developed some recommendation on informed consent. The SECPRE have long experience in claims because of defaults in informed consent and their indications are: "Informed consent documents must be delivered to patients with the greatest possible number of days preceding the procedure. The minimum is 24 hours. Actually, it has been demonstrated that the patient retains less than half 50 percent of which is discussed in the consultation." This is why we consider specially irregular to provide the informed consent in the same day of the intervention. But, as we have already reported, this information could not be confirmed personally at each centre.

The SECPRE also makes the following recommendation: "the consent with patient and doctor's sign must be filed with the clinical history but, also a signed copy of the informed consent document should be delivered to the patient." As in the previous issue, we were unable to verify this point at our sample but it would be very interesting to check this item on upcoming studies on the subject.

\section{Conclusions:}

Curettage procedures should have a more uniform protocol among public and private hospitals and clinics performing VIP. Mainly, all centres must follow the indications on the Law 41/2002, as well as recommendations from the model of the SEGO. As main recommendations we suggest the following:

- Before performing a curettage, the physician must provide the information both verbally and in writing, and ensure a proper understanding of the terms by the patient.

- It is mandatory to give informed consent adapted to the circumstances of each patient before the curettage.

- Informed consent must be provided with the maximum possible time before to the intervention if there is no medical emergency, and, at least, 24 hours before the the curettage.

- The physician should give to the woman a signed copy of the document of the informed consent at the time of signature.

- In the written form, the informed consent should make a reference to data protection, unless the patient had already signed at the centre a document of consent to the processing of personal data.

\footnotetext{
${ }^{2}$ Spanish Society of Aesthetic Plastic Surgery and Repair. Informed consent. Available online: http:// www.secpre.org/documentos\%20consentimiento.html. Checked in June 2009.
} 


\section{Acknowledgments:}

The authors want to thank to B. Pita, G. Ávila, M.J. de Luis, A. Caballín, T. Pérez, A. Santiago y J.A. Sánchez for their contributions and help in this work.

Table 1. Results of the comparison of the different items studied in the 30 models of written informed consent from 20 different centers, including SEGO and the Council of Health of Valencia.

\begin{tabular}{|c|c|c|c|c|c|c|c|c|c|}
\hline & \multicolumn{6}{|c|}{ Law $41 / 2002$} & \multicolumn{3}{|c|}{ SEGO Model } \\
\hline & 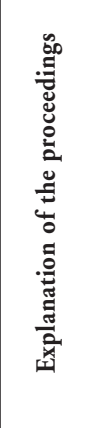 & 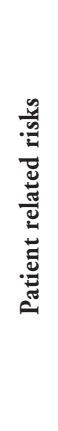 & $\begin{array}{l}\frac{n}{0} \\
-\frac{a}{2} \\
0 \\
0 \\
0 \\
0 \\
0 \\
0 \\
0\end{array}$ & 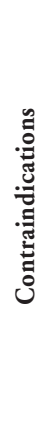 & 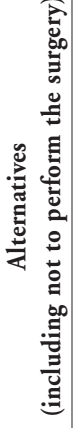 & 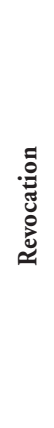 & 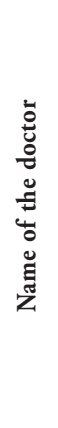 & 总 & 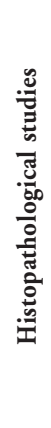 \\
\hline SEGO Model (V \& D) & Yes & Yes & Yes & No & No & Yes & Yes & Yes & Yes \\
\hline San José Clinic (V \& D) & SEGO & & & & & & & & \\
\hline $\begin{array}{l}\text { Asturias Hospital Universitario Central } \\
(\mathrm{V} \& \mathrm{D})\end{array}$ & SEGO & & & & & & & & \\
\hline Cabueñes` Hospital (Asturias) (V \& D) & SEGO & & & & & & & & \\
\hline San Agustín`s Hospital (Asturias) (V \& D) & SEGO & & & & & & & & \\
\hline $\begin{array}{l}\text { Talavera de la Reina`s Hospital (Toledo) } \\
\text { (V \& D) }\end{array}$ & SEGO & & & & & & & & \\
\hline Hospital Clínico de Granada (V \& D) & SEGO & & & & & & & & \\
\hline Hospital Universitario Gregorio Marañón (V) & + & + & + & No & Yes & Yes & Yes & No & Yes \\
\hline Alcorcón`s Hospital (V \& D) & + & No & $=$ & No & No & Yes & Yes & No & Yes \\
\hline Getafe`s Hospital (V \& D) & + & $=$ & $=$ & No & Yes & Yes & Yes & Yes & Yes \\
\hline Móstoles`s Hospital (V) & $=$ & + & + & No & No & Yes & Yes & Yes & Yes \\
\hline Madrid Hospitals Group (3 centers) (V \& D) & $=$ & $=$ & $=$ & No & No & Yes & Yes & Yes & Yes \\
\hline Moncloa Clinic - ASISA (V) & + & + & + & No & Yes & Yes & Yes & Yes & Yes \\
\hline Vistahermosa Clinic - ASISA (V) & + & + & + & No & Yes & Yes & Yes & Yes & Yes \\
\hline $\begin{array}{l}\text { Ginetec, Ginemédex and EMECE ( } 2 \text { centers) } \\
\text { Clinics (VIP) }\end{array}$ & - & $=$ & $=$ & No & No & No & Yes & No & No \\
\hline Isadora Clinic (VIP) & No & No & - & No & No & No & No & Yes & No \\
\hline Council of Health of Valencia (V \& D) & $=$ & $=$ & $=$ & No & Yes & Yes & Yes & No & No \\
\hline
\end{tabular}

Abbreviations: SEGO: Spanish Society of Gynecology and Obstetrics; V: vacuum curettage / aspiration; D: diagnostic curettage; VIP: voluntary interruption of pregnancy; (+): more information; (-): less information; = similar quantity of information. 